\title{
FOSTERING EXCELLENT TEACHING AND PRODUCTIVE STUDENT LEARNING
}

Promoviendo la enseñanza de calidad y el aprendizaje productivo de los alumnos Promovendo o ensino de qualidade e a aprendizagem produtiva dos alunos

\section{Sally Brown}

Emerita professor, Leeds Beckett University \& Independent consultant

Telephone: 00441912662369 / 7979 598781. E-mail: s.brown@leedsbeckett.ac.uk

\begin{abstract}
This keynote offers a personal perspective on some of the key drivers for excellent teaching in ways that can lead to productive student learning. Arguing that outstanding teaching can be fostered rather than being an innate skill, it presents some of the features that scholarship suggests characterise teaching excellence, which can then lead to focussed, engaged and sustainable student learning. Moving away from a transmissive model of content delivery, it will be suggested that authentic, meaningful and long-lasting learning relies on an active partnership between teachers and the taught and that assessment plays a key role in making this happen.
\end{abstract}

Keywords: excellent teaching; students as partners in learning; learning through assessment

\section{Resumen}

Esta conferencia ofrece una perspectiva personal de algunos de los factores clave para una enseñanza de calidad que pueda conducir a un aprendizaje productivo de los alumnos. Asumiendo que se puede aprender a ser un buen docente, más que constituir una habilidad innata, se presentan algunas de las características que el mundo académico sugiere como los rasgos de la enseñanza de calidad, que pueden conducir, entonces, a un aprendizaje por el alumno que sea centrado, involucrado y sostenible. Alejándonos de un modelo transmisivo de presentación de los contenidos, se sugerirá que el aprendizaje auténtico, significativo y prolongado se basa en una colaboración 
activa entre docentes y discentes y que la evaluación juega un papel importante en hacer que esto suceda.

Palabras clave: enseñanza de calidad; alumnos como colaboradores en el aprendizaje; aprendizaje mediante la evaluación

\section{Resumo}

Esta conferência apresenta uma perspetiva pessoal sobre alguns dos fatores chave para um ensino de qualidade, conduzindo a uma aprendizagem produtiva dos alunos. Assumindo que se pode aprender a ser um bom docente, muito mais do que constituir uma habilidade inata, se apresentam algumas das caraterísticas que o mundo académico sugere como sendo os fatores de um ensino de qualidade, que possa conduzir, por seu turno, a uma aprendizagem que seja centrada, envolvente e sustentável para o aluno. Baseando-nos num modelo transmissivo da apresentação dos conteúdos, sugere-se que a aprendizagem autêntica, significativa e prolongada se baseia numa colaboração ativa entre os docentes e discentes, e que a avaliação assume um papel importante no processo e para que isso aconteça.

Palavras-chave: ensino de qualidade; alunos como colaboradores na aprendizagem; aprendizagem mediante a avaliação

\section{Fostering excellent teaching and productive student learning}

Excellent teaching can lead to productive student learning if academics adopt a systematic and constructively-aligned approach to curriculum design, delivery and assessment (Biggs \& Tang, 2007) which recognises the importance of providing a cohesive student-centred approach. This is likely to entail using a whole-institutional focus, involving colleagues across the organisation to work together to provide an excellent curriculum through planning strategically in advance, designing authentic activities, using diverse methods for content delivery, offering thoughtful and inclusive student support, applying fit-for-purpose approaches to assessment and ensuring sound quality processes.

In this keynote, Sally Brown argues for a student-centred approach, which makes use of at least four decades of scholarship exploring what the best university and 
college lecturers do (Bain, 2004), how assessment can be a locus for improving student learning and engaging and how we can motivate and encourage students to achieve the best they can (Brown, 2015). A model for curriculum design essentials will be proposed, together with suggestions on how to assure robust quality of provision. In particular, the issue of how to engage $21^{\text {st }}$ Century students as partners in their own learning will be discussed, together with the key characteristics of outstanding university teachers. The model of curriculum delivery proposed is based upon Maieutic principles (Brown, 2015), that is causing students to produce learning rather than consume what others deliver.

A significant focus of the presentation will be around making assessment for rather than just of learning, adopting a fit-for-purpose approach (Sambell et al, 2012, Sambell et al, 2017) wherein assessment is integral and authentic, as a formative means of knowledge production rather than a simple summing up at the end of the process.

Ways of providing inclusive and targeted student support will be proposed and the case will be made that excellent teaching cannot happen without appropriate leadership and management. The keynote will conclude with a series of challenges to the audience to review how they can take forward the ideas put forward here within their own daily teaching practice.

\section{References}

Bain, K. (2004). What the best College Teachers do. Cambridge, MA: Cambridge Harvard University Press

Biggs, J., \& Tang, C. (2007) Teaching for Quality Learning at University: What the Student Does (3rd Ed.). Maidenhead: Open University Press/SRHE.

Brown, S. (2015) Learning, Teaching and Assessment in Higher Education: Global perspectives. London: Palgrave

Gibbs, G. (1999) Using assessment strategically to change the way students learn. In S. Brown \& A. Glasner (eds.), Assessment Matters in Higher Education: Choosing and Using Diverse Approaches (pp. 41-53). Maidenhead: SRHE/Open University Press. 
Sambell, K., McDowell, L., \& Montgomery, C. (2012) Assessment for Learning in Higher Education. Abingdon: Routledge.

Sambell, K., Brown, S. and Graham, L. (2017) Professionalism in Practice: key directions in higher education learning, teaching and assessment. London, New York, Palgrave Macmillan. 